\title{
National report on aggressions to physicians in Spain 2010-2015: violence in the workplace-ecological study
}

The National Observatory of Aggressions to Physicians (ONAM) Workgroup and General Council of Official Medical Associations of Spain (CGCOM)*

\begin{abstract}
Objective: Aggressions against health staff is a phenomenon that is not widely studied worldwide. To date, there is no national study analyzing this situation in Spain. Our objective is to describe and analyze aggressions to physicians of the whole Spanish territory in the period 2010-2015, through an observational analytical study by conglomerates (ecological) with all aggressions to physicians identified by the 52 official medical associations of Spain over 6 years of study.

Results: There were 2419 aggressions on physicians, $51 \%$ on men. Primary care is the area that concentrates more incidents (54\%) and the public sector is the most affected (89\%). A third of the assaults were concentrated on professionals aged 46-55 years old. Cumulative incidence decreased from 20 aggressions $\times 10,000$ physicians in 2010 to $15 \times 10,000$ physicians in 2015. The importance and seriousness of the problem of aggressions against physicians is verified through notifications to the registry. The collection method is different from others based on surveys, and therefore the figures are significantly lower than other studies. The scant denunciation by attacked physicians in Spain makes deceiving the real dimensions of the phenomenon.
\end{abstract}

Keywords: Aggression, Physician-patient relations, Workplace violence

\section{Introduction}

Aggressions against physicians is a problem of growing interest in research, which has been poorly prioritized in healthcare systems. To date and knowledge of the authors, there is no regulated study in Spain that analyzes this situation and its trend at national level in recent years. The number of related international studies is limited, most of them are old, without evidence of a prospective analysis of the phenomenon and with disparate results, which may well be the indirect reflection of the characteristics of different health care systems and organizations, or of the particular situation of each country [1].
Our objective is to contribute to the current state of knowledge of this problem in Spain and serve as a reference in the European region.

Until 2015 there are very few published studies related to this phenomenon in our society [20]. In 2015 a survey of physicians in Barcelona [2] described how $44 \%$ of the professionals surveyed stated that they had been victims of some form of verbal aggression. Another regional survey, this time carried out in Aragon and Albacete to 1845 health professionals concluded that up to $64 \%$ of the sample had suffered aggressions of different magnitude, and $5 \%$ acknowledged having been attacked on multiple occasions [3].

\section{Main text \\ Methodology}

The study has an observational design, and analyzes both the set of cases accumulated in 6 years, and its 
longitudinal evolution. It collects all the aggressions on physicians registered by the National Observatory of Aggressions to Physicians (ONAM) of the CGCOM from 1st January 2010 to 31st December 2015. The population under study $(\mathrm{N}=2419)$ is composed by of all physicians whose aggressions were registered by the 52 Official Medical Associations of Spain during this period. Each Medical Association reports its aggressions to the ONAM in a grouped manner, describing the scope of the professional practice in which they occur and the sociodemographic and professional characteristics of the physicians assaulted in each period. Considering that the general report of the ONAM is based on reports by clusters, the present study is ecological. The evaluation was anonymised.

\section{Aggressions}

We consider as an aggression each of the cases comprising physical or psychic attacks, insults or threats, which is communicated by the affected physicians to their respective Medical Association. We consider cluster, the report of aggressions of each Association to the ONAM. We have not excluded any of the detected aggressions.

\section{Other variables}

The information of the professionals assaulted on gender, age groups, type of professional exercise, presence of injuries, generation of (paid) sick leave (SL), reception of support/guidance by the company, presentation of a complaint, presence of previous aggressions and presence of material damages, and the information of the aggressor on personal background and profile, were obtained from the Annual Reports of the ONAM. Age variable was categorized into ranges $(<35,36-45,46-55$, $56-65, \geq 66$ years).

The type of professional practice was categorized as public and private. The scope of the aggression was categorized as primary care (GP practices), hospital, primary care emergencies (out of hours and domiciliary care), hospital accident-emergencies services, and others. The aggressor's personal history was categorized as drug addiction, psychiatric, organic disease and others. The profile of the aggressor was categorized as a scheduled patient, unscheduled patient, center user and family member. The other variables were dichotomized (yes/no) according to their presence or absence: personal injury, generation of temporary incapacity for work, reception of support/guidance by the company towards the physician attacked, presentation of a complaint, presence of previous aggressions and presence of material damages.

\section{Statistical analysis}

The descriptive analyses were based on frequency distribution and were performed on the total of aggressions observed in the study period. In the frequency analysis of each variable, only have been excluded the aggressions with lost data. For the accumulated incidence of aggressions, we used the number of assaults recorded each year, among the total number of collegiate doctors in the same period. P values were calculated using Pearson Square Chi or Fisher's Exact Test. All statistical analyses were performed using Stata software (version 11.1) [4].

\section{Results}

During the study period, there were 2419 aggressions on doctors in Spain, $50.8 \%$ on men and $49.2 \%$ on women. The great majority of the aggressions were detected in the public exercise (88.7\%). $37.3 \%$ of incidents were concentrated in the age group 46-55 years. Table 1 shows the frequency distribution of the main characteristics of the population.

\section{Cumulative incidence}

The cumulative incidence of aggressions against physicians in the period studied shows a significant tendency to decrease ( $P$ trend $<0.0001)$, observing a cumulative incidence of 20.2 assaults per 10,000 physicians in 2010 and 15 assaults per 10,000 physicians in 2015 (no significant differences between men and women).

\section{Aggressions by area}

Primary care concentrated more than half of the cases (53.9\%), followed by the hospital and Accident and Emergency Services (23.6\%).

\section{Severity of injuries}

Almost a fifth of the assaults on professionals during the study period were associated with personal injuries. Up to $12 \%$ of all attacks resulted in a SL. In 1 out of every 10 cases, material damages occurred and almost $8 \%$ of the physicians attacked had suffered prior attacks (Table 1). In a gender-stratified analysis of the aggressions recorded in 2015, no statistically significant differences were found in the proportion of physical and psychological injuries among men and women (Table 2).

\section{Aggressor profile}

Only 7 out of 10 aggressions are done by the patient; the others are generated by a relative or companion. Regarding the aggressor's antecedents, we found that $13 \%$ of aggressors had a history of psychiatric 
Table 1 Characteristics of the studied population 20102015

\begin{tabular}{|c|c|}
\hline Characteristics & Distribution \\
\hline \multicolumn{2}{|l|}{ Gender $(n=2401), \%$} \\
\hline Men & $1219(50.8)$ \\
\hline Women & $1182(49.2)$ \\
\hline \multicolumn{2}{|l|}{ Type of practice $(n=2342), \%$} \\
\hline Public & $2078(88.7)$ \\
\hline Private & $264(11.3)$ \\
\hline \multicolumn{2}{|l|}{ Age groups ( $n=1809$ ), years (\%) } \\
\hline$\leq 35$ & $254(14.0)$ \\
\hline $36-45$ & $494(27.3)$ \\
\hline $46-55$ & $675(37.3)$ \\
\hline $56-65$ & $353(19.5)$ \\
\hline$\geq 66$ & $33(1.8)$ \\
\hline \multicolumn{2}{|l|}{ Area $(n=1523), \%$} \\
\hline Primary care & $1267(53.9)$ \\
\hline Hospital & $341(14.5)$ \\
\hline Out-of-hospital emergency rooms & $225(9.6)$ \\
\hline Hospital emergency room & $215(9.1)$ \\
\hline Other areas & $303(12.9)$ \\
\hline \multicolumn{2}{|l|}{ Aggressor background ( $n=1385), \%$} \\
\hline Toxicomany & $108(7.8)$ \\
\hline Psychiatric & $184(13.3)$ \\
\hline Organic disease & $169(12.2)$ \\
\hline Unknown & $924(66.7)$ \\
\hline \multicolumn{2}{|l|}{ Aggressor profile $(n=1859), \%$} \\
\hline Scheduled patient & $604(32.5)$ \\
\hline Non scheduled patient & $451(24.3)$ \\
\hline Center user & $274(14.7)$ \\
\hline Relative or companion & $530(28.5)$ \\
\hline \multicolumn{2}{|l|}{ Personal injuries $(n=2346), \%$} \\
\hline Yes & $465(19.8)$ \\
\hline No & $1881(80.2)$ \\
\hline \multicolumn{2}{|l|}{ Sick leave $(n=2154), \%$} \\
\hline Yes & $263(12.2)$ \\
\hline No & $1891(87.8)$ \\
\hline \multicolumn{2}{|l|}{ Company support $(n=1697), \%$} \\
\hline Yes & $544(32.1)$ \\
\hline No & $1153(67.9)$ \\
\hline \multicolumn{2}{|l|}{ Formal complaint $(n=2283), \%$} \\
\hline Yes & $1655(72.5)$ \\
\hline No & $628(27.5)$ \\
\hline \multicolumn{2}{|l|}{ Previous aggressions $(n=2179), \%$} \\
\hline Yes & $168(7.7)$ \\
\hline No & $2011(92.3)$ \\
\hline \multicolumn{2}{|l|}{ Material damage $(n=2043), \%$} \\
\hline Yes & $213(10.4)$ \\
\hline No & $1830(89.6)$ \\
\hline
\end{tabular}

Values are expressed as absolute numbers and weighted percentages for categorical variables pathology, $12 \%$ of organic pathology and $8 \%$ of drug abuse; however, in the remaining $67 \%$ their medical history was unknown. It was significantly more frequent to find aggressions among the scheduled patients than among the non-programmed ones $(32.5 \%$ vs $24.3 \%$, $\mathrm{P}<0.0001$ ).

Causes related to aggressions: A cause could be identified in 1883 cases $(78 \%)$ of the total number of assaults recorded in the period. The discrepancies of the aggressor with the medical care provided motivated one of every three attacks and became the most frequent cause. Other aspects related to the medical act itself and the decision making by the professional, such as the prescription of medicines, the issuance of temporary in capacity, or the generation of reports $(11.9,5.8$ and $5.5 \%$ respectively) accounted for almost a quarter of the reported aggressions. Organizational aspects (waiting time, internal functioning, etc.) accounted for $15.4 \%$ of attacks (Table 3).

\section{Procedures after aggressions}

In only one-third of the attacks, the doctor received some support or advice from his institution. However almost $73 \%$ filed a complaint with the competent authorities.

\section{Discussion}

The phenomenon of aggressions against doctors during their professional practice is a latent phenomenon in many countries. However, in Spain, the number of published studies that analyze and quantify this situation is limited. A systematic review by Vidal-Marti et al. in 2014 [5] found only 16 articles on assaults in Spain published since 2000. And of these, only 6 analyze with quality the frequency of these events. At the international level, a systematic review by Nelsen et al. [6], finds only 12 studies published until 2013 that describe the prevalence of aggressions against physicians, but with results with a wide range (1.5-68.5\%).

Our results allow us to see incidences of aggressions against physicians, ranging from 15 to 20 assaults per 10,000 doctors in the period studied. These numbers are significantly lower than those described by different authors.

The area in which we found more aggressions was primary care with $54 \%$ of incidents, a frequency very close to $58 \%$ described in other Spanish studies [7-9] and to 63\% described in Anglo-Saxon studies [10]. Although we have not standardized the incidence rates of each of the areas studied, the greater proportion of professionals specialized in Family Medicine and the greater number of activities performed annually in primary care, we consider that explain the greater proportion of aggressions in this area. 
Table 2 Comparison of the aggressions to physicians by area and gender 2015

\begin{tabular}{llcll}
\hline Area & Men & Women & P value & Total \\
\hline PC $^{\mathrm{a}}(\%)$ & $90(50.3)$ & $103(56.6)$ & $\mathrm{NS}^{\mathrm{d}}$ & $193(58.3)$ \\
Hospital (\%) & $34(19.0)$ & $32(17.0)$ & $\mathrm{NS}^{\mathrm{d}}$ & $66(18.3)$ \\
PUCC $^{\mathrm{b}}(\%)$ & $15(8.4)$ & $20(11.0)$ & $\mathrm{NS}^{\mathrm{d}}$ & $35(9.7)$ \\
HER $^{\mathrm{c}}(\%)$ & $19(10.6)$ & $9(4.9)$ & $\mathrm{NS}^{\mathrm{d}}$ & $28(7.8)$ \\
Other areas (\%) & $21(11.7)$ & $18(9.9)$ & $\mathrm{NS}^{\mathrm{d}}$ & $39(10.8)$ \\
\hline
\end{tabular}

Values are expressed as absolute numbers and weighted percentages for categorical variables

a Primary Care

b Urgent Care Centers

c Hospital Emergency Rooms

d No significance

In our data, gender was not a differentiating factor in the incidence of aggressions, as described by multiple studies [11-16]. However, in the analysis of differences by gender and type of aggression, there are studies such as that by Miedema et al. describe a higher frequency of sexual harassment-related aggressions among women than among men $(60.7 \%$ vs $30.5 \%, \mathrm{P}<0.01)$ [17].

Although it has not been possible to calculate the rates of aggression by age group due to the absence of records, as it would have been necessary, it may be useful to make some comments on the distribution of age frequencies among the aggressed physicians. The age group with the highest proportion of recorded attacks was between 46 and 55 years old, a range higher than that described in other Spanish studies (30-43 years) [14-16, 18, 19]; but closer to the most affected ages described in international studies: Canada (44 years) [17], Australia (45-54 years old) [20] and Germany (55 years old) [17]. That is, our results support the hypothesis that the profile of the physician attacked is not necessarily a young physician with little experience as other authors have suggested [15, 21].
Low level aggressions (insults, threats) are not valued as serious by doctors in many cases, which is why they do not ask for help from the Medical Association and only communicate it to the contracting institution. Therefore the aggressions reported to the Medical Association may have a greater severity (Berkson selection bias): one out of every five aggressions had personal injuries and one out of every ten generated a SL and presented material damages. In fact, in other Spanish studies, the reported prevalence of physical damage is lower $[3,8,9,18,19,22]$.

Concerning the aggressor, it has been possible to identify his antecedents in a third of the cases, being the antecedents psychiatric and of drug addiction the most frequent, findings that coincide with those described by other authors [23-25].

\section{Conclusions}

Aggressions against health professionals are a severe problem with important consequences for any health system. The real magnitude has been silenced by the low claims of assaulted physicians. It is a global phenomenon, which is present not only in other European countries (Germany, France, Great Britain, Norway), but also in other continents. Although it is a multicausal situation, the loss of respect for the doctor, especially in primary care and in the emergency rooms has favored an increase in violent attitudes. Although the studies show that a large proportion of physicians have suffered from some aggression in their professional practice, only a small proportion formalizes the complaint to the competent authorities.

It is decisive, within the clinical management, to take measures aimed at the prevention of aggressions and the attention to injured professionals, always starting from an individualized analysis of the work environment and the factors that can favor such situations. For this, it is

Table 3 Identified causes of aggressions to physicians in Spain 2010-1015

\begin{tabular}{|c|c|c|c|c|c|c|c|}
\hline Cause related to the aggression & $2010 \mathrm{~N}(\%)$ & $2011 N(\%)$ & $2012 N(\%)$ & $2013 N(\%)$ & $2014 N(\%)$ & $2015 N(\%)$ & Total $N(\%)$ \\
\hline Discrepancies with healthcare & $99(31.3)$ & $166(39.3)$ & $113(35.5)$ & $93(32.1)$ & $81(30.8)$ & $98(35.8)$ & $650(34.5)$ \\
\hline No prescription of desired medicine & $38(12.0)$ & $56(13.3)$ & $44(13.8)$ & $33(11.4)$ & $25(9.5)$ & $29(10.6)$ & $225(11.9)$ \\
\hline Waiting time & $36(11.4)$ & $37(8.89$ & $35(11.0)$ & $34(11.7)$ & $34(12.9)$ & $37(13.5)$ & $213(11.3)$ \\
\hline Personal discrepancies & $31(9.8)$ & $25(5.9)$ & $34(10.7)$ & $25(8.6)$ & $30(11.4)$ & $42(15.3)$ & $187(9.9)$ \\
\hline Related to work incapacity & $21(6.6)$ & $24(5.7)$ & $19(6.0)$ & $22(7.6)$ & $15(5.7)$ & $8(2.9)$ & $109(5.8)$ \\
\hline $\begin{array}{l}\text { Medical reports that are not in accordance with } \\
\text { the patient's requests }\end{array}$ & $23(7.3)$ & $17(4.0)$ & $11(3.5)$ & $25(8.6)$ & $13(4.9)$ & $15(5.5)$ & $104(5.5)$ \\
\hline Disagreement with the functioning of the centre & $13(4.1)$ & $16(3.8)$ & $13(4.1)$ & $11(3.8)$ & $12(4.6)$ & $12(4.4)$ & $77(4.1)$ \\
\hline Other causes & $55(17.4)$ & $81(19.2)$ & $49(15.4)$ & $47(16.2)$ & $53(20.2)$ & $33(12.0)$ & $318(16.9)$ \\
\hline Total & 316 & 422 & 318 & 290 & 263 & 274 & $1883(100)$ \\
\hline
\end{tabular}

We describe the sample size in each period. Values are expressed as absolute numbers and weighted percentages for categorical variables 
important to maintain and develop research on this phenomenon.

Achieving the intervention of legislative and executive authorities, as it is already happening in Spain, for the recognition of the health professional as an authority $[25,26]$, can be the long way to go through other environments where the frequency of these events is increasing.

\section{Limitations}

- Although the ONAM reports have a national character, as authors we are aware that the cases of aggressions reported to medical associations usually coincide with cases of greater severity, so that there may be an important under-registration of aggressions of less severity that never get to be reported by the professionals involved, being that the main limitation of our work. For our analysis, this can lead us to underestimate the real magnitude of the problem, justifying the low incidences found, lower than those described by other authors. That fact therefore limits the validity of the data provided and invites cautious interpretations of the results.

- As authors, we would like to point out that this is the first analytical study to explore ONAM consolidated information throughout Spain, and although its results are not directly comparable with other studies related to methodological differences, the analysis provides relevant data on the characteristics and typology of the aggressions to physicians, and constitutes a Spanish and European referent for future investigations.

\section{Abbreviations}

ONAM: Observatorio Nacional de Agresiones a Médicos (National Observatory of Aggressions to Physicians); SL: sick leave.

\section{Authors' contributions}

The authors listed in the article have collaborated collectively in the production of this study. All authors read and approved the final manuscript.

\section{Author details}

${ }^{1}$ General Council of Official Medical Associations of Spain (CGCOM), Plaza de las Cortes, 11, 28014 Madrid, Spain.

\section{Acknowledgements}

There are no personalized acknowledgments that should be recorded. The National Observatory of Aggressions to Physicians (ONAM) Workgroup-General Council of Official Medical Associations of Spain (CGCOM) -Garrote-Díaz JM, M.D., Ph.D.

Secretary General, General Council of Official Medical Associations of Spain, Madrid; jmgarrote@cgcom.es

Becerra-Becerra A, M.D.

Secretary General, Official Medical Association of Badajoz; secretario@ colegiomedicobadajoz.org

Bendaña-Jácome J, M.D.

Secretary General, Official Medical Association of Orense; secretariagral@ cmourense.org

Casero-Cuevas L, M.D.
Secretary General, Official Medical Association of Ciudad Real; secretario@ comciudadreal.org

Garrote-Cuevas G, M.D.

Secretary General, Official Medical Association of Cádiz; ggarrotesemergen@hotmail.com

Muñoz-García M, M.D.

Presidency, Official Medical Association of Ávila; medhiguera@semg.es Marín-Montero R, M.D.

Secretary General, Official Medical Association of Córdoba; rmmarmon@ telefonica.net

Perez-Gallego L, M.D.

Secretary General, Official Medical Association of Zamora; secretariogeneral@colmeza.com

Gutierrez-Bejarano D, M.D., M.P.H

dayro979@gmail.com

Repullo JR, M.D.

Foundation for Training of the Spanish Medical Association, jrepullo@ ffomc.org

\section{Competing interests}

The authors declare that they have no competing interests, since it is promoted from the Medical Colleges with their own resources, to identify the magnitude of a problem, such as aggressions at work, which affects its members.

\section{Availability of data and materials}

The datasets used and/or analysed during the current study are available from the corresponding author on reasonable request.

\section{Consent for publication}

Not applicable.

\section{Ethics approval and consent to participate}

The data come from registered records of incidents of aggressions produced to doctors during a period of time.

ONAM is a technical body of the General Council of Medical Associations, whose General Secretariat has sponsored the study and provided the necessary records for its realization.

\section{Funding}

The research has been carried out with the resources of the Medical Colleges, and it has not been necessary to obtain or assign additional specific funding.

\section{Publisher's Note}

Springer Nature remains neutral with regard to jurisdictional claims in published maps and institutional affiliations.

Received: 1 February 2018 Accepted: 3 May 2018

Published online: 04 June 2018

References

1. Morken T, Alsaker K, Johansen $\mathbf{H}$. Emergency primary care personnel's perception of professional-patient interaction in aggressive incidents-a qualitative study. BMC Fam Pract. 2016;12(17):54

2. Gómez-Durán EL, Gómez-Alarcón M, Arimany-Manso J. Las agresiones a profesionales sanitarios. Rev Esp Med Legal. 2012;38(1):1-2.

3. Martínez-Jarreta B, Gascón S, Santed MA, Goicoechea J. Medical-legal analysis of aggression towards health professionals. An approach to a silent reality and its consequences on health. Med Clin (Barc) 2007:128(8):307-10.

4. StataCorp LP. Stata Statistics/Data Analysis. StataCorp LP; 2010. http:// www.stata.com. Accessed 26 Apr 2018.

5. Vidal-Martí C, Pérez-Testor C. Violencia laboral hacia los profesionales sanitarios en España. Rev Esp Med Legal. 2015:41(3):123-30. 
6. Nelsen AJ, Johnson RS, Ostermeyer B, Sikes KA, Coverdale JH. The prevalence of physicians who have been stalked: a systematic review. J Am Acad Psychiatry Law. 2015;43(2):177-82.

7. León MM, Muñiz MJJl, León CM, Sierra MTC, Burón DQ. Estudio de las agresiones a los profesionales sanitarios. Revista de la Escuela de Medicina Legal. 2011;0(17):4-11.

8. Moreno Jiménez MA, Vico Ramírez F, Zerolo Andrey FJ, López Rodríguez A, Herrera Serenab P, Mateios Salidoc MJ. Análisis de la violencia del paciente en atención primaria. Aten Primaria. 2005:36(3):152-8

9. De-San-Segundo M, Granizo JJ, Camacho I, Martínez-de-Aramayona MJ, Fernández M, Sánchez-Úriz MÁ. A comparative study of aggression towards Primary Care and Hospital Health professionals in a Madrid health area (2009-2014). Semergen. 2016.

10. Hobbs FD. Fear of aggression at work among general practitioners who have suffered a previous episode of aggression. Br J Gen Pract. 1994;44(386):390-4.

11. Alexander C, Fraser J. Occupational violence in an Australian healthcare setting: implications for managers. J Healthc Manag. 2004;49(6):377-90

12. Koritsas S, Coles J, Boyle M, Stanley J. Prevalence and predictors of occupational violence and aggression towards GPs: a cross-sectional study. Br J Gen Pract. 2007;57(545):967-70.

13. Miedema BB, Hamilton $R$, Tatemichi S, Lambert-Lanning A, Lemire F, Manca $D$, et al. Monthly incidence rates of abusive encounters for canadian family physicians by patients and their families. Int J Family Med. 2010;2010:387202.

14. Gutiérrez L, Hernández MJ, Molina L. Work-related violence among public health professionals (2008-2012). Arch Prev Riesgos Labor. 2016;19(3):166-74.

15. Mayorca Yancán IA, García Silvia L, Cortés Martínez ME, Lucerna Méndez MA. Violencia contra trabajadores sanitarios en un hospital de Andalucía: ¿Por qué hay agresiones no registradas? Med Segur Trab (Internet). 2013;59(231):235-58.

16. Trujillo-Diaz N. Agresividad en el Ambito Sanitario. 5o Congreso Andaluz de Medicina Familiar y Comunitaria. Huelva-España; 2016.
17. Miedema B, Hamilton R, Lambert-Lanning A, Tatemichi SR, Lemire F, Manca $D$, et al. Prevalence of abusive encounters in the workplace of family physicians: a minor, major, or severe problem? Can Fam Physician. 2010;56(3):e101-8.

18. Consejo de Medicos del Pais Vasco. Encuesta sobre Agresiones a Facultativos de la Comunidad Autonoma Vasca. 2015.

19. Rincón-Del Toro T, Villanueva-Guerra A, Rodríguez-Barrientos R, Polentinos-Castro E, Torijano-Castillo MJ, de Castro-Monteiro E, et al. Aggressions towards primary health care workers in Madrid, Spain, 2011-2012. Rev Esp Salud Publica. 2016;25(90):e1-12.

20. Magin PJ, Adams J, Sibbritt DW, Joy E, Ireland MC. Experiences of occupational violence in Australian urban general practice: a cross-sectional study of GPs. Med J Aust. 2005;183(7):352-6.

21. Grant D. US report on violence in the medical workplace may hold lessons for Canadian MDs. CMAJ. 1995;153(11):1651-2.

22. Martínez-León M, Queipo Burón D, Muñiz I, Jesús M, Martínez-León C. Análisis médico-legal de las agresiones a los profesionales sanitarios en Castilla y León (España). Rev Esp Med Legal. 2012;38(1):5-10.

23. Vorderwülbecke F, Feistle M, Mehring M, Schneider A, Linde K. Aggression and violence against primary care physicians-a nationwide questionnaire survey. Dtsch Arztebl Int. 2015;112(10):159-65.

24. El Martinez-Leon M. riesgo emergente que constituyen las agresiones y violencia que sufren los médicos en el ejercicio de su profesión: el caso de España. Revista Bioética [en linea]. 2010;18(2):263-74.

25. Marinas-Sanz R, Martínez-Jarreta B, Casalod Y, Bolea M. Aggressions towards healthcare workers in Spain: status after the recent modification of the Spanish Penal Code. Med Clín (English Edition). 2016;147(1):35-42.

26. Martinez-Leon M, Queipo Burón, Martinez Leon CC, Torres-Marin H. Aspectos Médico-Legales de las Agresiones al Personal Sanitario y su consideración como Delito de Atentado. Sideme. 2010;5. Sociedad Iberoamericana de Derecho Médico (SIDEME). http://www.sideme.org/revis ta/num5/martinez_leon_Sideme5.pdf. Accessed 26 Apr 2018.
Ready to submit your research? Choose BMC and benefit from:

- fast, convenient online submission

- thorough peer review by experienced researchers in your field

- rapid publication on acceptance

- support for research data, including large and complex data types

- gold Open Access which fosters wider collaboration and increased citations

- maximum visibility for your research: over $100 \mathrm{M}$ website views per year

At BMC, research is always in progress.

Learn more biomedcentral.com/submissions 